\author{
Милош М. КОВАЧЕВИЋ ${ }^{*}$ \\ Филолошки факултет Београд \\ Филолошко-уметнички факултет Крагујевац
}

Оригинални научни рад

Примљен: 11.11.2019.

Прихваћен: 12.2.2020.

\title{
ЋИРИЛИЦА - СЛУЖБЕНО А УПОТРЕБНО ОДУМИРУЋЕ ПИСМО КОД СРБА
}

\begin{abstract}
У раду се даје кратак осврт на статус који је ћирилица имала у прошлости код Срба, на њене честе прогоне, зато што је сматрана основном идентитетском српском особином. Рад се највећим дијелом бави актуелним статусом ћирилице, посматраним кроз саоднос двају термина: „службене употребе” и „јавне употребе” језика и писма. Показано је како је дошло до надређивања појма „јавна употреба” појму „службена употреба”. Описано је какво је рјешење у погледу употребе тих двају појмова дато у Изменама и допунама Закона о језику и писмима, које је, уз сарадњу са Одбором за стандардизацију српскога језика, направило и 2017. године Влади Републике Србије прослиједило Министарство културе и информисања Републике Србије. Суштина датих измјена своди се на то да укидањем термина ,јавна употреба” ћирилица добије статус какав предвиђа актуелни устав: да (п) остане једино службено писмо иијелога српскога народа.

Кључне ријечи: српски идентитетски критеријуми, српски језик, ћирилица, службена употреба језика и писма, јавна употреба језика и писма, Закон о језику и писмима
\end{abstract}

На питање о актуелном употребном статусу ћирилице у српском језику** - одговор је готово самоочигледан. Сигурно је да никада ниједно писмо - сем српске ћирилице - није ниподаштавано од властитог народа, или боље речено: од оних који тај народ тобож као његова елита представљају. Иако је ћирилица једино српско национално писмо, иако она Србе прати од почетака писмености до данас, у посљедњем стољећу она код Срба бива све више потискивана латиницом, и све чешће њом замјењивана. А латиницу је највећи број Срба добио тек почетком двадесетог вијека. Она је дошла заједно са уласком Хрвата у заједнички државу - најприје Краљевину Срба, Хрвата и

*mkovacevic31@gmail.com

** Овај рад готово у цјелини, уз одређене стилске модификације, преноси ставове из различитих ауторових радова објављених у књизи Борба за ћирилииу и српски језик (Ковачевић 2018 : 15-130). Рад је, дакле, својеврсни сажетак тих радова. 
Словенаца, а онда и Југославију. У читавом 20. вијеку ћирилица је на различите начине „бацана у сјенку” латинице, све док није доспјела у „дубоки хлад” из кога никако не може да се врати „на свјетлост дана”.

Крвави крај заједничке државе, у коју су Срби уложили толико живота и илузија, није, нажалост, донио српско отрежњење. Истина, Срби су се декларативно враћали провјереним националним вриједностима, међу којима је и ћирилица. Али, чини се, само декларативно. Мада је ћирилица у Србији и уставом (из 2006. године) прописана као једино писмо у службеној употреби, она ни данас, у односу на латиницу, нема ништа бољи употребни статус неголи јуче. Разлози томе су вишеструки. Најприје, погрешно схватање да глобализацијски енглески језик нужно за собом повлачи употребу латинице, а напуштање ћирилице. Заборавља се или намјерно превиђа да таман колико ни Русима нити Бугарима ћирилица није препрека у учењу енглеског или било ког другог језика који се пише латиницом, то она не може бити ни Сpбима. Учење страних језика нити је било нити је садашњи разлог све већег одумирања ћирилице код Срба. А ако се то и може уврстити у разлоге, онда тај разлог свакако не улази у круг оних примарних, него је далеко на периферији. Примарне разлоге треба тражити на другој страни. А понајприје у склоности српскога народа, или боље рећи његове утицајне „интелектуалне елите" за самопорицањем властитих националних вриједности. У које несумњиво спада и ћирилица.

Савремени српски књижевни језик и савремену српску ћирилицу повезује исти реформатор - Вук Стефановић Караџић. Вук је сматрао да „српскијех језика нема више до само један, којијем говори народ српски” (Караџић 1969: 211), а да том језику, за кога велики Лаза Костић написа „да га љепшега на свијету нема" (Костић 1990: 227), најбоље ако не и једино као писмо одговара ћирилица - реформисана, у којој ће свакоме српском књижевном гласу одговарати једно слово (графема). Таква хармонија једнога језика и једнога писма никада и негдје у свијету - сем у српскоме језику и у српској ћирилици - није остварена. Зато кад се год каже српски језик, он имплицира и ћирилицу као примарно српско писмо, а кад се год помене ћирилица, она истовремено призива и српски језик. Зато је ћирилица неотуђиви дио српскога језика, и зато је српски језик у свој пуноћи српски тек кад се исписује ћирилицом. Та два термина једино у српском језику, између свих језика на кугли земаљској могу метонимијски да се замјењују: кад се каже српски језик нужно се мисли и на српску ћирилицу, а кад се каже српска ћирилица, то истовремено значи и српски језик.

Тога прожимања и интердепенденције српскога језика и српске ћирилице у историји нису били свјесни само Срби него и њихови непријатељи. Тако историја потврђује да су не тако ријетко у покушајима затирања Срба њихови непријатељи тежили ка укидању ћирилице као иманентне идентитетске српске карактеристике. Будући да је у романтичарском периоду формирања нација језик био основни идентитетски критеријум, Вук је Србима сматрао све оне који говоре српским језиком, без обзира кога су вјерозакона (укључујући у Србе и православце, тј. оне „закона грчкога”, и римокатолике, 
тј. оне „закона римскога”, и муслимане, тј. оне „закона мухамеданскога”, јер их је уједињавао српски језик као темељни критеријум националног идентитета). А будући да је ћирилица била иманентна карактеристика Вуков(ск) ог српског језика, она се управо у 19. и 20. вијеку у покушајима истребљења Срба - морала наћи на удару, јер се сматрало да се њеном забраном Србима укида једне од њихових најсуштаственијих националних особина. Прва званична забрана употребе ћирилице - обавјештава нас Јелица Стојановић - „везана је за име царице Марије Терезије 1779. године. Под наговором римских првосвештеника издата је наредба да се ћирилица укине изван цркве, и да се у школе под морање уведе „простонародни језик илирски и латиница” (Стојановић 2011: 74). Сви Срби у данашњој Војводини, заједно са митрополитом и епископима, устали су против такве наредбе, тако да је наредба повучена. Након смрти Марије Терезије, њен син цар Фрањо Јосиф II обновио је ову наредбу 3. фебруара 1781. Највећи удар на ћирилицу извршен је у Првом свјетском рату, и то опет од аустријских власти. У вријеме Првог свјетског рата ћирилица је била званично забрањена у Хрватској, Босни и Херцеговини, Црној Гори и Србији. Прогон ћирилице није мимоишао ни Други свјетски рат. Само десетак дана након преузимања власти, 25. априла 1941, Независна Држава Хрватска објелоданила је Законску одредбу о забрани ћирилице, коју прати Проведбена наредба министра унутрашњих послова законској одредби о забрани ћирилице, у којој се наводи: „Забрањује се свака упораба ћирилице на цијелом подручју Независне Државе Хрватске”, а и „Свако штампање ма каквих књига ћирилицом је забрањено. Сви јавни натписи писани ћирилицом имају се неодвлачно, а најкасније у року од три дана скинути" (Самарџија 1993: 40-41).

Иако је код Хрвата једино у времену НДХ законски забрањена њена употреба, однос Хрвата према ћирилици није био много бољи ни у временима прије и послије НДХ. Ћирилица се сматрала иманентном особином српства, једном од најбитнијих диференцијалних карактеристика која је одвајала Хрвате од Срба. Хрвати су се, једноставно речено, грозили ћирилице као једног од најпрепознатљивијих српских обиљежја. Тај свој став исказали су не само у времену НДХ него и у времену актуелне самосталне Хрватске, која је међу првим својим законско-образовним поступцима имала прогон ћирилице из школе и јавне употребе, али и изгон ћириличких књига из готово свих хрватских књижница (библиотека) (Ковачевић 2013: 67-68). Још бољи показатељ о ћирилици као битној српској националној особини представља став Аустроугарске према ћирилици током Првога свјетскога рата. Тако је у Хрватској ћирилица укинута 3. јануара 1915; у Босни и Херцеговини наредбом Земаљске владе у Сарајеву употреба ћирилице је забрањена 10. новембра 1915. Забрана ћирилице није се, међутим, ограничила само на Хрватску и Босну и Херцеговину. Након окупације Црне Горе 1916. године аустријска власт је 18. септембра 1916. забранила употребу ћирилице. У Србији је пак одлуку о забрани ћирилице у јавној употреби донио Војни генерални гувернеман за Србију 12. јуна 1916. године. Завладавши свим државама у којима је живио српски народ, Аустроугарска је у свима њима најприје укинула ћири- 
лицу сматрајући је основном српском идентитетском карактеристиком. Врло је симптоматично, кад се пореди с аргументима данашњих антићириличара, образложење којим је Аустроугарска укинула ћирилицу у Србији. Аустроугарска је, наиме, сматрала да у Хабзбуршкој царевини „сви народи могу да остваре свој цивилизацијски искорак. А да би српски народ то учинио, морало му се 'помоћи' да се ослободи својих заблуда. Када је култура у питању, као највећа препрека укључењу српског народа у цивилизацију видело се његово писмо - ћирилица” (Ђорђевић 2014: 7).

Срби су се, међутим, увијек враћали ћирилици као свом једином националном писму, као неотуђивом дијелу свог националног идентитета, као - како је то на једноме мјесту исправно и прецизно речено - „стожерној вертикали српског духовног, културног и историјског идентитета” (Марковић ред. 1998: 12).

Најзначајнији, али нажалост формални а не стварни, повратак ћирилици и одређењу њеног законодавно-правног статуса означио је актуелни Устав Републике Србије из 2006. године, у коме је у члану 10. начела Устава, под одредницом „Језик и писмо” прописано: „У Републици Србији у службеној употреби су српски језик и ћириличко писмо. Службена употреба других језика и писама уређује се законом, на основу Устава”.

А устав је највиши правни акт у систему правних аката једне државе. Из самог устава изводе се и уставност и законитост унутар једне државе. Уставност подразумијева да у једној држави постоје уставом утврђена основна друштвена правна правила, која обезбјеђују да се државна власт на основу њих организује и спроводи објективно, с тим да нико не може имати више власти или овлашћења него што то предвиђају уставом утврђена правна правила. Законитост, пак, подразумијева да сви правни акти морају бити у складу са законом. Без заштите уставности, односно законитости нема правне државе, односно владавине права. А механизми заштите уставности и законитости у свакој су држави утврђени уставом. Зато уставност у ужем смислу значи сагласност са уставом свих прописа (закона, уредби, одлука, правилника, наредби, рјешења и др.). А та сагласност подразумијева хијерархију општих правних аката, од устава као највишег према законима и подзаконским актима као нижим, с тим да хијерархијски нижи нивои права морају бити усклађени са хијерархијски вишим нивоима права. Из тога онда проистиче да ниједан законски и подзаконски акт не може бити у супротности с уставом као највишим правним актом, тј. да сваки законски и подзаконски акт мора бити сагласан с уставом као највишим општим правним актом једне државе.

Од доношења Устава 2006. године до ево године 2020. (дакле, пуних 14 година) још није донесен нови Закон о језику и писму у Републици Србији, нити је Закон о службеној употреби језика и писма из 1991. године усаглашен са наведеним чланом 10. Устава Републике Србије, тј. није измијењен и допуњен како с обзиром на уставом прописану службену употребу језика и писма, тако ни с обзиром на чињеницу да Устав одређује да се „службена употреба других језика и писама уређује законом, на основу Устава”. Не- 
бројено пута су многи појединци, не само лингвисти, и не само различита удружења за заштиту ћирилице, констатовали, и многим установама и/или институцијама културе скретали пажњу о непоштовање уставне одредбе о имену језика и о ћирилици као његовом једином писму. (исп. нпр. више од 60 дописа и документа које доноси Јањатовић 2011). Али, „када су Срби или њихове институције у питању, од њих нормално понашање не треба ни очекивати нити се у институције уздати”, јер се „наша власт понаша по дубоко утемељеним комунистичким обрасцима и она законе доноси не да би их поштовала него да би их примитивно игнорисала" (Петровић 2016: 765).

На сваки помен о нужности практичне примјене уставне одредбе о службеном статусу српског језика и ћирилице у медијима би се на препознатљив „антисрпски” начин огласили представници „грађанистичке” или „друге Србије” настављајући деведесетих година започети „културни рат”, чијег је садржаја и циља суштина „порицање или ниподаштавање одређених културних вредности, а његов главни облик је понижавање, исмевање, цинизам у односу на главне симболе и носиоце" (Антонић 2008:10). А међу те симболе свакако спада и ћирилица.

Највећи проблем примјене уставног рјешења у пракси јесте тај што Устав не прописује, јер то у његов домен и не потпада, шта подразумијева појам „службене употребе”. Питање садржаја појма „службена употреба" компликује безмало 30 године неизмијењени српски Закон о службеној употреби језика и писма (из 1991), који појму „службене употребе” супротставља појам ,јавне употребе језика и писма".

А појам ,јавне употребе”- присутан у српском закону о језику и писму, а непознат српскоме уставу - хрватска је заоставштина у српском законодавству и језичкој политици. Појам ,јавне употребе” Србима су подарили Хрвати. И да чудо буде веће, кад су Хрвати од тог појма одустали, кад су га избацили из свог законодавства и језичке политике - он је остао да живи само код Срба.

Термин ,јавна употреба језика” оригинални је хрватски „изум”, који су Хрвати увели у законодавну (језичкоправну) употребу, и то најприје у Амандману V на Устав СР Хрватске (16. 2. 1972), који је постао члан 138. Устава СР Хрватске из 1974. године:

\footnotetext{
„У Социјалистичкој Републици Хрватској у јавној је употреби хрватски књижевни језик - стандардни облик народног језика Хрвата и Срба у Хрватској, који се назива хрватски или српски.” (Стефановић 2015:119-120; 2017а).
}

Да се тај термин и данас примјењује у српској законодавно-правној пракси, најбољу потврду пружа Закључак Уставног суда Републике Србије бр. ІУз-309/2013 од 24. децембра 2013. године, којим се као ,апсолутно неоснован" одбија Предлог за очену уставности и законитости члана 40. Закона о трговини (СГ бр. 53/2010, 10/2013) који је 2. септембра исте године поднео г. Драгојло Лековић из Београда. Он је оспорио други став, који одређује да „сви подаци о роби [...] морају бити наведени на јасан, лако уочљив начин, на српском језику на ћириличком или латиничком писму.” 
Добио је следеће образложење разлога за одбијање предлога о оцени уставности: „Према схватању Уставног суда, употреба латиничког писма и страних језика и писама у смислу оспореног члана 40. Закона о трговини не може се сматрати службеном употребом језика и писма у смислу Закона о службеној употреби језика и писама и члана 10 Устава, већ спада у домен јавне употребе језика и писама који се у уставноправном смислу може законом уредити на предвиђени начин, па нису основане тврдње да оспорене законске одредбе нису у сагласности са Уставом." (Стефановић 2015: 129; 2016: 369).

Наведени Закључак Уставног суда Републике Србије траже научни (језичкополитички) одговор на најмање три битна питања: а) шта подразумијева термин „службена употреба језика и писма”; друкчије речено, је ли то само „облик комуникације између државних и локалних органа власти с једне стране и грађана и других субјеката с друге”, б) шта подразумијева термин ,јавна употреба језика и писма”, и в) какав је међуоднос „службене и јавне употребе језика и писама".

Уставни суд Републике Србије последњом реченицом Закључка показује да јавна употреба језика и писма у Републици Србији није законски уређена, него да се „у уставноправном смислу може законом уредити на предвиђени начин”. То, међутим, није могуће ако се појам ,јавне употребе” супротстави појму „службене употребе”.

Познати српски лингвиста, професор Новосадског универзитета Драгољуб Петровић наводи да су врло чести случајеви „у којима се помиње службена и јавна употреба језика, посебно када се ради о законском прецизирању уставних одредаба о мањинским језицима и њиховим писмима" и наставља да он „никад није успео схватити која је разлика између тих 'двеју употреба' и вероватно је то измислио неки комунистички законодавац да би могао терорисати здрав разум носилаца српскога језика" (Петровић 2016: 767).

Англиста Ранко Бугарски, као један од најватренијих заговорника јавне употребе језика и писма, каже да ,za razliku od službene upotrebe, javna ироtreba jezika u svetu je nepoznata kao priznata ustavna kategorija, pa je ne treba eksperimentalno uvoditi u Srbiji. Taj pojam je toliko širok $i$ neodređen da se ne može podvesti pod zakonske paragrafe bez izazivanja haosa u javnoj komunikaciji, otvaranjem širokog prostora za proizvoljna tumačenja, selektivnu primenu, pa $i$ golu represiju. Dejstvo koje se ovom novinom verovatno imalo u vidu mnogo se bezbolnije može postići preciziranjem pojma službene upotrebe jezika i pisma, vodeći računa o tome da će Ustav i na njemu zasnovani zakoni da važe na celoj teritoriji Srbije, a ne samo tamo gde je potreba za ovakovom regulativom najizraženija. [...] Osim toga, zakon koji bi pretendovao na to da ozbiljno i podrobno uredi javnu upotrebu jezika i pisma ne može se kako valja napisati, poštovati niti sprovoditi"' (Бугарски 1995: 67-68, 72).

${ }^{1}$ Истицања у свим цитатима у овом раду су накнадна, тј. моја - МК. 
Да је ,јавна употреба” специфичност само српског језика, потврђује и чињеница да се у свим европским језицима, језицима Европске уније, говори само о службеној (“official") и приватној (“individual"), а у Хрватској о „личној” употреби језика и писма, и да се баш нигдје не говори о ,јавној употреби” која је супротстављена „службеној”. Појам службени језик користи се и у законодавству већег броја земаља у Европи и изван ње. Тај се појам дефинише и у лексиконима, енциклопедијама и сличним приручницима (енг. official language, нем. die Amtsprache). Овим појмом обухвата се употреба језика у цјелокупном јавном животу једне земље. Томе је науспротна српска вјештачка подјела на двије сфере јавне употребе језика - службену јавну (општење државних органа, органа покрајинске аутономије и локалне самоуправе, јавних предузећа и јавних служби, установа, предузећа и других организација када врше јавна овлашћења) и неслужбену а јавну (употреба језика у школама и другим образовним и научноистраживачким установама, јавним гласилима, медијима, привредним предузећима и установама на осталим подручјима јавног живота), које се, та службена и неслужбена јавна употреба, ни у теорији ни у пракси не могу досљедно одвојити нити диференцирати.

Однос између јавне и службене употребе по правилу се дефинише принципом негативног релационог идентитета. Тако ће Ранко Бугарски рећи да „јавна [употреба] обухвата све што није приватно, укључујући службену употребу као један свој мањи, али посебно важан сегмент. Ова последња [тј. службена - МК] покрива рад државних органа, њихову комуникацију међусобно и са грађанима, дипломе, табле на надлештвима, путне ознаке и слично. Између приватне и службене употребе постоји огроман преостали простор јавне употребе, у који спадају највећи део школства и издаваштва, скоро сви медији, јавна предавања, дискусије, филмови, позоришне представе, неслужбена културна и друштвена комуникација итд.”2 (Бугарски 2017).

Према критеријуму негативног релационог идентитета однос приватне, јавне и службене употребе одређује и правник Радомир Лукић, с Правног факултета на Палама. Он каже да ,приватна употреба језика обухвата сваки вид употребе језика у друштвеном саобраћају који уставом и законом није одређен као вид службене или јавне употребе језика" (Лукић 2018:110), наглашавајући да се „у правним изворима [не наводи за потврду ниједан! МК] прави одређена разлика између јавне употребе језика и писма и језика и писма у службеној употреби. Службена употреба језика и писма само је један део њихове јавне употребе, али онај његов део који има посебан значај због тога што се односи на употребу језика у вршењу тзв. (државне и јавне) службе, односно државне власти и тзв. јавне службе (јавних служби) ${ }^{3}$. [...]

${ }^{2}$, „домену јавног комуницирања припадају настава у свим врстама школа, све књиге и новине, радио, телевизија, филм и позориште, јавне трибине, политички говори и стручна предавања, научни рад, пословна кореспонденција између наших фирми и са иностранством, курсеви страних језика, потом уговори, обрасци, фирме, плакати и још много тога” (Бугарски 1995: 71).

${ }_{3}$ „При томе се сам појам службе најчешће не одређује, односно не дефинише у законима о (службеној) употреби језика, због чега се значење овог појма мора пронаћи или у анализи прописом одређених појединачних облика који се сматрају службеном употребом језика (об- 
Код таквог стања ствари, јавна употреба језика би била свака правом регулисана употреба језика која се не сматра службеном употребом језика и писма. Дакле, одређивала би се, како се то уобичајено каже, 'по остатку', од језика у службеној употреби” (Лукић 2018:112).

Дате дефиниције ,јавне употребе”, будући релационе и негативне, заправо и нису праве дефиниције, па се из њих не може уопште спознати шта је садржај појма ,јавна употреба", тако да се не може направити ни законско (терминолошко) диференцирање ,јавне” и „службене” употребе језика и писма.

Како је дошло до термина ,јавна употреба" и његовог дјелимичног супростављања термину „службена употреба” у бившој СФРЈ и Србији као њеној конститутивној републици, у науци је детаљно - уз освјетљење историјата тог термина и навођења свих релевантних докумената као научне подлоге за закључивање - осветњено (Стефановић 2015, 2016, 2017), па је готово навјероватно да се и данас у правном систему Србије сусрећу оба термина.

Наиме, термин ,јавна употреба језика"4, као и многе друге, измислили су Хрвати у бившој заједничкој држави. Израз ,јавна употреба хрватског књижевног језика" дат је, како смо већ констатовали, први пут у амандману V на Устав СРХ од 16. фебруара 1972. године, који је постао чл. 138. Устава СР Хрватске из 1974. године. А идеолошко покриће за политички продукт „jавна употреба хрватског књижевног језика" пронађено је у изворном учењу лењинизма, а представио га је књижевник Мирко Божић, тада потпредсједник Сабора СР Хрватске и предсједник саборског Одбора за међунационалне односе на сједници РК ССРН Хрватске одржаној 3. новембра 1972: „Утврдивши име у јавној употреби и народно име језика Хрвата и Срба у Хрватској, Устав је само утврдио чињеницу. Живот ће дати дух и садржај језику. За нас су битне управо садржајне функције и димензије језика: знанствене, културне, социолошке, друштвене, комуникативне. У контексту тог става хуманог, толерантног, културног - Устав и не наглашава службеност језика, иако говори о језику у јавној употреби. Увијек треба имати на уму Лењинов став о језику, о равноправности и о службености језика" (цитирано према: Стефановић 2015: 120-121). Из датог се образложења види да је термину „службена употреба” претпостављен термин ,јавна употреба”, будући да су термини заправо сматрани синонимима.

Увођењем термина ,јавна употреба језика” појавио се проблем уједначавања терминологије на простору српскохрватског језика у цјелини. Тај

разовање, издаваштво, топографске ознаке насеља, удружења националних, верских, етничких и језичких мањина и др.) или се, пак, његово одређење мора тражити у (систематској) вези са другим правним изворима, односно законима који овај појам или њему сродне појмове одређују за потребе неке друге правне гране, подгране или неког другог појединог правног извора. [...] Она би могла да обухвати и неке јавне службе, као што су школство, односно образовање уопште, означавање топографских назива насељених места и сл., зато што се ради о употреби која је блиска употреби у раду државних органа и органа јавних служби када правно одлучују општим или појединачним актом, мада се од њих разликује неким својим својствима" (Лукић 2018: 111-112).

${ }^{4}$ Историјат увођења и примјене термина ,јавна употреба” овдје у виду сажетка дајемо на основу резултата истраживања С. Стефановића $(2015,2016,2017)$. 
проблем био је усложњен чињеницом да уставна рјешења ни у осталим републикама српскохрватског језика нису била униформна: у Србији и није било терминолошког одређења него је српскохрватски језик био само „у употреби”, у БиХ и Црној Гори српскохрватски је био „службени језик”, са равноправношћу обају писама - и ћирилице и латинице. Неуједначеност је још више усложнио хрватски устав увођењем термина ,јавна употреба”. Та шароликост резултирала је отпочињањем дебата о језичком и терминолошком компромису. Хрватски књижевни језик „у јавној употреби” био је, наиме, у асиметричном положају у односу на српскохрватски који је био „службени”, односно „у употреби”. „Јавна употреба” постала је уставна и односила се само на „хрватски језик”, али она није добила дефинисан садржај, била је само сурогат „службеној употреби”.

У Србији је, под утицајем Хрватске и по угледу на њу, израз ,јјавна употреба" уведен на самом почетку осамдесетих година, и то у фусноти, ${ }^{5}$ у оквиру предлога за измене устава СР Србије, који је изнио Бранислав Брборић (2000: 241-291), али није направљена његова значењска дистинкција према изразу „службена употреба”. Мишљења о ,јавној употреби” била су врло подијељена, а то се најбоље види по компромисном карактеру Амандмана бр. XXVI Уставне комисије Скупштине СР Србије од 7. јануара 1989. године. Задржане су и „службена” и ,,јавна” употреба, а њихов однос је требало да буде регулисан законом. Тај XXVI амандман је гласио:

„У Социјалистичкој Републици Србији у службеној и јавној употреби је српскохрватски језик и његова писма - ћирилица и латиница.

У Социјалистичкој Републици Србији, на подручјима на којима живе поједине народности, у равноправној службеној и јавној употреби су српскохрватски језик и језици тих народности и њихова писма, у складу са Уставом и законом."

Овакво решење дошло је петнаест година након што је уведено у Устав Хрватске. И управо кад су Срби прихватили хрватско становиште (што им није први пут!), Хрвати су свој терминолошки изум одбацили, и оставили га Србима да с њим бригу брину. Наиме, након „donošenja ustava 22. prosinca 1990. hrvatski jezik je postao službenim jezikom Republike Hrvatske" (Самарџија 2013: 15).

У околностима када су Хрвати одустали од израза који су сами увели, и вратили се изразу који су употребљавали и Срби и остали народи „српскохрватског језика” у својим уставима, у формулацији Устава Србије од 28. септембра 1990. године израз ,,јавна употреба" формално је напуштен. ${ }^{6}$ Али се он у примјени задржао у Закону о службеној употреби језика и писама $(1991,1994,2005,2010)$, тако да тај Закон и „није написан на основу

\footnotetext{
${ }^{5}$ Та фуснота Б. Брборића гласи „Боље је рећи 'јавној' него у 'службеној' употреби (о јавној се говори у Уставу СРХ, а службеној у Уставу СРБиХ и СРЦГ), јер су и језици народа у 'службеној употреби', а овдје је ријеч о јавној употреби стандардне новоштокавштине у контексту њене дефиниције, која је потребна стога што је она једини наш језик којим говори више нација и који је обиљежен варијантским разноликостима” (Брборић 2000: 283).

${ }^{6}$ У Уставу Србије из 1990, члан 8 гласи: „У Републици Србији у службеној је употреби српскохрватски језик и ћириличко писмо, а латиничко писмо је у службеној употреби на начин утврђен законом.

На подручјима Републике Србије где живе народности у службеној употреби су истовремено и њихови језици и писма, на начин утврђен законом”.
} 
уставног решења из 1990. године, већ на основу већ цитираног Амандмана бр. XXVI из 1989” (Стефановић 2015: 126).

Управо из тих разлога неопходно је као основ за израду новог српског Закону о службеној употреби језика и писама узети Устав (и онај из 1990, и онај из 2006), а напустити (јер га је напустио чак и Устав из 1990, а камоли да није онај из 2006) Амандман бр. XXVI из 1989. године. Баш због тога неопходно је у српском Закону о службеној употреби језика и писма дати термину „службена употреба језика и писма” садржај који он има у свом језицима, па сад и у тзв. „хрватском” из кога је и преузет. Друкчије речено, у закону треба да постоје термини „службена” и „приватна или лична” употреба језика и писма у јавној комуникацији, јер се ти термин „дају дефинисати, a 'јавне употребе' нема, јер је логички - тиме ни правно - не може ни бити" (Стефановић 2017а).

У том новом Закону треба, дакле, потпуно избацити термин ,јавна употреба”, односно под термин „службена употреба” подвести цијелу јавну употребу, уз навођење случајева који не подразумијевају службену употребу језика и писма. А то су сљедећи случајеви:

a) приватна комуникација која искључује „службене контексте” употребу језика и писма,

б) писање и употреба личних имена,

в) двојезичне публикације, књиге и компјутерски програми (осим њихових описа и упутстава),

г) прихваћена научна и техничка терминологија,

д) научна и умјетничка дјела,

ђ) научна и образовна дјелатност школа на страним језицима, двојезичких школа, курсева страних језика, што је предмет посебних прописа,

е) марке произвођача и роба, и ознаке поријекла роба и услуга.

Све друга подручја употребе потпадају под службену употребу српског језика и ћириличког писма. Термин „службена употреба” не треба мотивацијски повезивати са термином ,државна служба", ${ }^{7}$ јер таква повезаност из

\footnotetext{
${ }^{7}$ Што је очигледно случај са одређеним доменом службене употребе у Закону о службеној употреби језика и писама Србије (1991):

Члан 2.

(1) Службеном употребом језика и писама, у смислу овог закона, сматра се употреба језика и писама у раду: државних органа, органа аутономних покрајина, градова и општина (у даљем тексту: органи), установа, предузећа и других организација кад врше јавна овлашћења (у даљем тексту: организације које врше јавна овлашћења).

(2) Службеном употребом језика и писама, у смислу овог закона, сматра се и употреба језика и писама у раду јавних предузећа и јавних служби, као и у раду других организација кад врше послове утврђене овим законом.

Члан 3.

(1) Службеном употребом језика и писама сматра се нарочито употреба језика и писама у:

1) усменом и писменом општењу органа и организација међусобно, као и са странкама, односно грађанима;

2) вођењу поступка за остваривање и заштиту права, дужности и одговорности грађана;
} 
службене употребе искључује чак и употребу језика у васпитно-образовном систему, него му (за)дати значење „нормативна или узакоњена употреба”, док термин приватна (лична) употреба треба да има значење „ненормативна или неузакоњена употреба”. Такви садржаји ових термина налазе свој пандан нпр. код термина „стандардни/књижевни језик” и „нестандардни/некњижевни језик (идиом)".

Укидањем термина ,јавна употреба" и ћирилица ће добити статус какав је предвиђа актуелни устав. (П)остаће једино службено писмо ичиелога српскога народа. Али да би до тога дошло, неопходно је да се српска политичка и филолошка дјеловања нађу на истом путу, на путу заустављања ништења српског националног идентитета због неуважавања значаја српског језика и српске ћирилице као основних националних одредница. На том послу потребно је да се нађу све српске институције и сви српски филолози и утицајни политичари. У вези с тим, неопходно је што прије усвојити написани и у фиокама владе већ више од двије године затурени нови закон о језику и писму. Без тога ћирилица ће неумитно бити све рјеђа и рјеђа у употреби, док потпуно не изумре и постане историјско писмо српскога језика и српскога народа.

\section{ЛИТЕРАТУРА}

Антонић 2008: Слободан Антонић, Културни рат у Србији, Београд: Завод за уџбенике.

Брборић 2000: Бранислав Брборић, О језичком расколу: Социолингвистички огледи I, Београд: Центар за примењену лингвистику, Нови Сад: Прометеј.

Бугарски 1995: Ranko Bugarski, Jezik od mira do rata, drugo, dopunjeno izdanje, Beograd: Slovograf.

Бугарски 2017: Ранко Бугарски, „Јавна употреба језика”, Политика, 7. 10. 2017.

Ђорђевић 2014: Бојан Ђорђевић, „Музе нису ућутале: културни живот Срба током Великог рата у огледалу тадашње штампе”, у: Бојан Ђорђевић, Драгана Грујић, Гордана Ђоковић, Летопис културног живота током

3) вођењу прописаних евиденција од стране општинских органа и организација које врше јавна овлашћења на територији општине (у даљем тексту: евиденције);

4) издавању јавних исправа, као и других исправа које су од интереса за остваривање законом утврђених права грађана;

5) остваривању права, дужности и одговорности радника из рада или по основу рада.

(2) Службеном употребом језика и писама сматра се и употреба језика и писама при: исписивању назива места и других географских назива, назива тргова и улица, назива органа, организација и фирми, објављивању јавних позива, обавештења и упозорења за јавност, као и при исписивању других јавних натписа. 
Великог рата: 1916-1918, Београд: Институт за књижевност и уметност, Нови Сад: Матица српска.

Јањатовић 2016: Ђорђе Јањатовић, Битка за ћирилицу: наставак, Нови Сад: Удружење за заштиту ћирилице српског језика „Ћирилица”.

Караџић 1969: Вук Стеф. Караџић, О језику и кюижевности, Београд: Просвета.

Ковачевић 2013: Милош Ковачевић, „Хрватска својатања историје српске ћирилице", у: Милош Ковачевић, У одбрану српске ћирилице: хрестоматија, Пале: СКПД „Просвјета”, 67-72.

Ковачевић 2018: Милош Ковачевић, Борба за ћирилицу и српски језик, Андрићград: Андрићев институт.

Костић 1990: Лаза Костић, $O$ књижевности и језику, Нови Сад: Матица српска.

Лукић 2018: Радомир В. Лукић, „Право и приватна, јавна и службена употреба језика и писма", у: Говори српски - пиши ћирилицом (приредио мр Рајко Танасијевић), Београд: Филип Вишњић, 108-121.

Марковић (ред.) 1998: Слово о српском језику, уредник Ангелина Марковић, Београд: Фонд истине о Србима.

Петровић 2016: Драгољуб Петровић, „Битка за ћирилицу или битка с ветрењачама", поговор за књигу: Ђорђе Јањатовић, Битка за ћирилицу: наставак, Нови Сад: Удружење за заштиту ћирилице српског језика „Ћирилица”, 765-777.

Самарџија 1993: Marko Samardžija, Hrvatski jezik u Nezavisnoj Državi Hrvatskoj, Zagreb: Hrvatska sveučilišna naklada.

Самарџија 2013: Marko Samardžija, Politika, zakonodavstvo i jezik, Zaprešić: Hrvatsko filološko društvo, Hrvatska sveučilišna naklada.

Стефановић 2015: Синиша Стефановић, „О јавној употреби језика и писма”, Векови: историјски часопис Андрићевог института, бр. 2, Андрићград: Андрићев институт, Одјељење за историју, 109-138.

Стефановић 2016: Синиша Стефановић, „Ћирилица у Уставу Србије: преглед значајније изворне грађе (1974-2014)", Култура, бр. 152, Београд, 2016, 350-374. <http://scindeks-clanci.ceon.rs/data/pdf/0023-5164/2016/002351641652350S.pdf>

Стефановић 2017: Синиша Стефановић, „Србија и њен ћирилички стандард”, Политика, 26. 8. 2017, КУН, 7.

Стефановић 2017а: Синиша Стефановић, „Криво срастање”, Политика, 30. 9. 2017.

Стојановић 2011: Јелица Стојановић, Путевима српског језика и ћирилице, Никшић: Издавачки центар Матице српске - Друштво чланова у Црној Гори. 


\section{Miloš Kovačević}

\section{CYRILLIC - OFFICAL BUT IN USE DISAPPEARING SCRIPT OF SERBS}

\section{Summary}

The paper gives a brief overview of the status that the Cyrillic alphabet had in the past among Serbs, its frequent persecutions, because it was considered a basic Serbian identity trait. For the most part, the paper deals with the current status of the Cyrillic script, discussed through the correlation of two terms: "official use" and "public use" of language and script. It is shown how the notion of "public use" came to be superior to the notion of "official use". It describes the solution regarding the use of these two terms given in the Amendments to the Law on Language and Scripts, which, in cooperation with the Committee for Standardisation of the Serbian Language, was made and forwarded to the Government of the Republic of Serbia in 2017 by the Ministry of Culture and Information. The essence of the given changes comes down to the fact that by abolishing the term "public use", the Cyrillic alphabet gets the status envisaged by the current constitution: to remain the only official script of the entire Serbian nation.

Keywords: Serbian criteria of identity, Serbian language, Cyrillic, offical use of language and script, public use of language and script, Law on Language and Scripts 